\title{
EFEK WACANA TERORISME ATAS \\ PELARANGAN MASUK WARGA \\ NEGARA ISLAM KE AMERIKA SERIKAT
}

\section{Ahmad Jamaludin}

Program Interdisciplinary Islamic Studies, Universitas Islam

Negeri Sunan Kalijaga Yogyakarta konsentrasi Kajian Timur

Tengah jmldn90@gmail.com

\begin{abstract}
Abstrak
Artikel ini membahas keterkaitan wacana terorisme dengan kebijakan Amerika Serikat yang melarang warga negara Islam masuk ke AS. Wacana terorisme selain menjadi permasalahan global, secara lebih khusus menjadi masalah bagi negara-negara Islam karena senantiasa distigma sebagai negara teroris. Dalam kancah hubungan internasional, persoalan ini kian mempersulit negara-negara Islam untuk menjalin hubungan dengan negara lain. Dari penelusuran tersebut ditemukan kesimpulan bahwa selain meraih dukungan politik dalam negeri dan luar negeri AS, wacana terorisme di kancah internasional semakin memperlebar ketimpangan antara negaranegara Maju dengan negara-negara Islam Berkembang.

This article examines relation between terrorism discourse and United States of America's policy of restricting people from Islam countries to enter USA. Terrorism discourse is global problem, especially for Islam countries because they used to stigmatize as terrorist countries. In international relation field, this problem interferes Islam countries to build relationship with others. From this examination writer found conclusion that discourse of terrorism used by USA government to grab internal and external political support and in other hand increase the gap between leading countries and Islam as developing countries in international field.
\end{abstract}

Kata Kunci; Terorisme, Negara Islam, Amerika Serikat, dan Hubungan Internasional. 


\section{Pendahuluan}

Pasca berakhirnya Perang Dingin yang membaiat Amerika Serikat sebagai negara adidaya tunggal, perang ideologi liberal melawan komunis seolah padam. Namun hal tersebut tak berlangsung lama. Satu dekade kemudian, pada permulaan abad 21 dunia internasional kembali guncang setelah menyaksikan runtuhnya gedung World Trade Center (WTC), yang jadi simbol supremasi AS, akibat serangan teror. Sembilan pria anggota $\mathrm{Al}$ Qaeda membajak empat pesawat komersil AS dan menabrak masing-masing gedung kembar WTC, gedung Pentagon, dan yang terakhir jatuh di ladang dekat Shansville, Pennsylvania. Total korban meninggal dalam serangan teror tersebut adalah 2,977 orang. Gedung kembar WTC menjadi fokus utama karena selain jumlah korbannya yang besar, 2,753 orang meninggal, juga menjadi pusat ekonomi dunia (CNN Library, 2018). Peristiwa yang terkenal sebagai September Hitam itu seolah jadi penanda titik balik kabijakan politik luar negeri AS yang sempat melunak pasca kekalahan dan keruntuhan Uni Soviet dalam Perang Dingin.

AS pada masa Perang Dingin lebih mengedepankan langkah persuasif dalam menjalin relasinya dengan negara lain. Namun pasca peristiwa September Hitam perang terhadap teror menjadi retorika utama politik luar negeri agresif AS. Sasaran pertama perang AS terhadap terorisme adalah Al Qaeda, pihak yang mendaku bertanggung jawab atas peristiwa teror September Hitam. Al Qaeda yang mengusung ideologi Islam kemudian menjadi paralel sederhana untuk identitas teroris di mata AS. Namun belakangan terkuak bahwa retorika perang terhadap teror ini berkelindan dengan kepentingan politik dan ekonomi AS di kancah internasional.

Pandangan AS tersebut menjadi determinan penting atas wacana Islam sebagai agama teror di kancah internasional. Hal mencolok kiwari yang bisa dirujuk adalah kebijakan pemerintah AS yang melarang tujuh warga negara Islam masuk ke negaranya di awal 2017. Kebijakan tersebut secara resmi dikeluarkan presiden AS, Donald Trump, pada tanggal 27 Januari 2017. Tujuh negara Islam yang terdampak yakni Iran, Iraq, Libya, Somalia, Sudan, Suriah dan Yaman yang warga negaranya dilarang masuk ke AS dalam kurun 90 dan 120 hari untuk pengungsi (BBC Newsround, 2017). Pelarangan itu diberlakukan dengan 
alasan demi menjaga warga AS dari ancaman teroris. Secara eksplisit Trump mengatakan bahwa, "Saya membangun langkah-langkah baru ini untuk menjaga teroris Islam radikal keluar dari Amerika. [Saya] tidak ingin mereka di sini" (Suastha, 2017).

Meski kebijakan ini mendapat perlawanan dari dalam negeri AS sendiri karena dianggap melanggar hukum dan konstitusi, Trump tetap kukuh menjalankannya. Kebijakan pelarangan muslim sempat melonggar dengan dihapusnya Irak dan Syria dari daftar negara terlarang. Namun pada Juni 2017 pembendungan itu kembali mengetat pasca kebijakan Trump ditetapkan oleh Mahkamah Agung AS sebagai kebijakan yang sah dan tidak melanggar konstitusi. Kebijakan ini mengalami pasang surut, namun tidak lantas membuka pintu secara lebar untuk warga negara Islam masuk ke AS. Pada September 2017, kebijakan yang kerap disebut sebagai 'larangan muslim bepergian' ini kembali direvisi dengan enam negara Islam masuk daftar larangan yaitu Iran, Chad, Libya, Somalia, Syria, Yaman (BBC Newsround, 2017). Kebijakan versi baru ini kembali mendapat gugatan hukum, sehingga pada April 2018 direvisi lagi dengan menghilangkan Chad dari daftar. Namun pada Juni 2018 Mahkamah Agung AS kembali menetapkan legalitas kebijkan pelarangan tersebut. (Taylor, 2018). Atas kemenangan versi ketiga kebijakan pelarangan muslimnya ini Trump berkata bahwa ia akan senantiasa menjaga AS dari serangan terorisme dan ekstrimisme (Shear, 2018).

Jika merujuk ke belakang, kebijakan ini searah dengan kampanye Trump pada tahun 2015 sebelum terpilih, bahwa cara melindungi warga AS dari teroris Islam adalah dengan menerapkan pembatasan kunjungan. Trump lantas menjanjikan program "penutupan total dan menyeluruh bagi muslim-muslim memasuki Amerika Serikat" yang mulai ia jalankan seminggu setelah memasuki Gedung Putih (independent, 2017). Dalam taraf tertentu Trump sekadar mengeksplisitkan retorika yang menstereotip Islam sebagai identitas atau ideologi teror di AS pasca September Hitam.

\section{Islam dan Terorisme}

Islam dan terorisme menjadi dua kata yang seolah identik pasca teror 9/11. Dalam wacana politik global keidentikan Islam dan terorisme mengemuka akibat kampanye besar AS dalam "war 
against terrorism." Jika dilihat dari sekup dan efeknya pada hubungan internasional, perang atas terorisme ini telah setara dengan Perang Dingin karena melibatkan banyak aspek seperti keamanan, ekonomi, hukum, pemerintahan, dan politik (Jackson, 2018). Dalam konteks ini wacana terorisme bisa dilihat sebagai sebuah praktik kekuasaan yang erat kaitannya dengan dinamika politik global. Lebih spesifik wacana terorisme berupaya mengkonstruksi suatu subjek teror dalam relasinya dengan negara (Ditrych, 2014).

Walter Reich berpendapat bahwa terorisme secara garis besar bisa didefinisikan sebagai, "Suatu strategi kekerasan yang dirancang untuk meningkatkan hasil -hasil yang diinginkan, dengan cara menanamkan ketakutan di dalam masyarakat." Dengan mengutip Brian Jenkins, Hendropriyono menambahkan bahwa terorisme cenderung digunakan untuk mencapai sebuah tujuan politik (Hendropriyono, 2009). Oleh karena itu retorika perang terhadap teror bisa diartikan sebagai perang antar kekuatan politik.

Merujuk pada pengertian terorisme di atas, tidak ada keterkaitan langsung antara Islam (sebagai agama atau ideologi) dengan terorisme. Namun dalam konteks war against terrorism-nya AS, cukup terang kiranya bahwa AlQaeda selaku dalang dibalik peristiwa 9/11 telah diidentifikasi sebagai subjek teror. Hal tersebut lantas diperkuat oleh wacana dalam laporan-laporan media massa yang menggambarkan kekerasan dan kebrutalan Al Qaeda adalah akibat fanatisme keagamaan dan doktrin jihad dalam Islam melihat bahwa pelekatan Islam dengan terorisme adalah efek dari retorika yang bergerak liar mengikuti logika global yang dikomandoi AS dalam war againt terrorism (Hasan, 2012). Peran wacana terorisme dan kebijakan politik luar negeri AS pasca 9/11 berperan besar dalam pelabelan atas Islam tersebut. Dalam pidato presiden AS, George W. Bush, di depan Dewan sepuluh hari setelah peristiwa $9 / 11$, menyebut terorisme adalah praktik dari ekstrimisme Islam yang menghendaki pembunuhan terhadap Kristen, Yahudi, dan Amerika (Guardian, 2001).

Tindakan teror yang dilakukan Al Qaeda bisa juga dikategorikan sebagai Islam Politik. Islam Politik adalah sebuah gejala sosial-politik yang dicirikan oleh tiga hal: (1) Aktor, (2) aktivisme, (3) ideologi (Hasan, 2012). Dalam peristiwa 
9/11 kita tahu pelakunya adalah $\mathrm{Al}$ Qaeda yang notabene adalah kelompok sosial yang beragama Islam, sehingga Al Qaeda adalah aktor. Penyerangan gedung kembar WTC dan Pentagon adalah bentuk aktivisme atau gerakan yang dilakukan oleh aktor sebagai sebuah manifestasi dari ideologi. Islam bisa dianggap sebagai ideologi karena mempunyai konsep kekuasaan dan tata sosial tertentu (Hasan, 2012).

Meski sebenarnya keduanya berbeda, agama dan ideologi dalam beberapa aspek memiliki karakter dan tujuan yang sama. Masing-masing menghendaki penjelasan- atas dunia sekitar, menawarkan suatu program untuk dijalankan, dan tujuan untuk dicapai. Keduanya bisa dibedakan dari metode penjelasannya atas dunia, agama menerangkan realita dengan pendekatan ketuhanan dan supranatural, sedangkan ideologi lebih kepada rasio dan penjelasan sistematis. Namun ada dua aspek penting mengapa agama bisa berfungsi sebagai ideologi, (1) otoritas yang dimiliki agama bisa menjadikannya ideologi, karena tendensi penjelasan ilmiah ideologi adalah untuk mencapai suatu otoritas. (2) ketika sain didamaikan dengan dogma agama yang akan memberikan penjelasan ilmiah sebagaimana ideologi (Desai, 2007).

Beberapa istilah juga hadir seiring menguatnya wacana terorisme antara lain; fundamentalisme, radikalisme, dan jihadisme (Arif., 2010). Dalam wacana terorisme global doktrin jihad dalam Islamlah yang dianggap menjadi pemicu merebaknya terorisme. Karena itu publik internasional cenderung memahami bahwa dalam ajaran Islam terdapat konsep yang melegalkan kekerasan dan teror. Jihad sendiri dalam bahasa arab berarti "perjuangan" atau "usaha yang bersungguh-sungguh" untuk mencapai tujuan. Jihad dalam Islam jadi relevan manakala ada pengingkaran hukum-hukum tuhan di ranah sosial. Sehingga amar ma'ruf nahy munkar (memerintah kebenaran dan melarang kejahatan) perlu dilakukan (Arif., 2010). Dalam aspek longgar, jihad bisa dipahami sebagai penegakan kebaikan di ranah sosial.

Namun jihad, dan secara spesifik jihadisme, memiliki definisi lain ketika dikaitkan dengan wacana teorisme. Jihadisme bisa didefinisikan sebagai pemikiran, wacana, dan aksi yang memaknai jihad secara eksklusif sebagai perang suci dan menggunakannya untuk melegitimasi kekerasan 
untuk mencapai tujuan. Jihadisme kemudian menjadi salah satu varian dari Islam Politik. Karena karakter kekerasan yang melekat tersebut, jihadisme dianggap sebagai benih terorisme, atau lebih tepatnya disebut terorisme atas nama Islam (Hasan, 2012).

\section{Politik Luar Negeri di Kancah Internasional}

Politik luar negeri suatu negara pada dasarnya adalah kombinasi kondisi dalam negeri dan situasi internasional (Wuryandari, 2011). Dalam aspek tersebut bisa dijelaskan bahwa kebijakan perang atas terorisme AS adalah representasi kondisi internal AS yang lantas memengaruhi dinamika politik internasional. AS yang kuat dalam persenjataan, ekonomi, dan politik internasional sekaligus salah satu dari lima Dewan Keamanan Perserikatan Bangsa-Bangsa jelas mampu mempengaruhi dinamika politik internasional dengan kebijakan luar negerinya. Oleh karena itu politik luar negeri AS yang agresif dalam perang atas terorisme kemudian mendiskreditkan Islam dan warga negara Islam yang senantiasa menjadi simplifikasi wajah terorisme di kancah internasional.
Kebijakan politik Trump yang membendung masuknya beberapa warga negara Islam menjadi episode lanjutan kebijakan politik luar negeri AS dalam perang atas terorisme. Adapun argumen yang dipakai Trump dalam pelarangan tujuh warga negara Islam masuk ke AS di awal 2017 adalah mereka masuk dalam kategori "negaranegara yang diwaspadai". Negaranegara itu dianggap memiliki organisasi teroris atau menjadi tempat berlindung para teroris (Goodman, 2017).

Secara lebih konkret pelarangan ini berkenaan dengan imigran dan pengungsi yang mungkin masuk ke AS. Pemerintah AS hendak membendung masuknya warga negara Islam karena dianggap mengancam keamanan warga negaranya. Pemerintah AS juga melakukan pengetatan ijin masuk dengan menerapkan sistem pembuatan surat pernyataan guna memperoleh ijin masuk AS. Dengan jumlah 80 juta warga negara Islam yang disinyalir terdampak kebijkaan tersebut, terbukti hanya sebagian kecil saja yang bisa memperoleh ijin masuk. Hingga 30 April 2018, dari 33,176 surat pernyataan yang masuk, hanya 576 surat atau $2 \%$ yang disetujui oleh departemen 
terkait (Gladstone \& Sugiyama, 2018).

Meski sejak awal kebijakan pembendungan muslim sangat kontroversial, ternyata tidak banyak pemimpin negara-negara di dunia yang menolaknya secara tegas, kecuali beberapa negara Islam yang terdampak dan bersimpati seperti Irak dan Indonesia (Taylor, 2018). Dalam kancah dunia internasional bisa dibilang kebijakan ini tidak mengganggu kepentingan AS dalam menjalin hubungan dengan negara lain. Bahkan Arab Saudi yang notabene negara Islam dan dekat dengan AS tidak memberi pernyataan apapun terhadap kebijakan pelarangan Trump yang telah belangsung selama hampir dua tahun tersebut. Sehingga kebijakan politik luar negeri AS berkenaan dengan terorisme yang mendiskreditkan negara-negara Islam tersebut tidak berefek buruk bagi posisinya di kancah Internasional.

Faktor dukungan internal yang solid telah tampak melalui bertahannya kebijakan pelarangan muslim masuk ke AS hingga versinya yang ketiga disahkan oleh Mahkamah Agung pada Juni 2018. Namun politik luar negeri bukanlah representasi kondisi politik internal saja, ada aspek eksternal yang mesti dipertimbangkan, yakni dinamika dunia internasional (Wuryandari, 2011). Dalam kancah internasional, penting untuk dicatat bahwa tidak banyak pemimpin negara-negara maju yang meresponnya. Minimnya respon negara maju semakin menerangkan realitas politik internasional yang unipolar pasca Perang Dingin dengan AS sebagai kekuatan utama di kancah internasional.

Ada beberapa perubahan mendasar kondisi politik internasional sebelum dan sesudah Perang Dingin. Karakter utama realitas global ketika Perang Dingin adalah,

(1) kondisi bipolar yang membagi wilayah dunia menjadi dua blok, AS selaku blok barat dan Uni Soviet sebagai blok Timur. (2) pertentangan ideologi didominasi oleh kapitalisme dengan komunisme.

(3) konflik dan kekerasan terjadi di negara dunia ketiga (Wuryandari, 2011). Sedangkan kondisi setelah Perang Dingin lebih berkarakter seperti berikut, (1) realitas politik internasional yang unipolar, dengan Amerika Serikat sebagai pusat. (2) pertentangan ideologi telah bergeser menjadi Barat-Islam seiring munculnya tesis benturan peradaban dan 9/11. (3) konflik dan kekerasan telah merambah hingga dunia pertama, meskipun perang 
tetap berkobar di negara dunia ketiga terutama kawasan Timur Tengah.

Berubahnya konstelasi politik internasional tersebut mengakibatkan politik luar negeri berbagai negara mesti menyesuaikan. Dalam konteks ini kebijakan politik luar negeri AS yang cenderung mendiskriminasi negara-negara Islam tampak tidak banyak mendapat tantangan karena posisi kuatnya di kancah internasional. Penolakan yang disampaikan oleh Inggris dan Perancis saat pertama dimunculkan gagasan 'pelarangan muslim bepergian' tidak muncul lagi dalam versi ketiga pelarangan muslim tersebut, bahkan Perancis berbalik mendukungnya (Taylor, 2018). Sebaliknya, stigma teroris yang kerap ditempelkan pada negaranegara Islam membuat mereka sulit menegosiasikan kepentingannya di kancah internasional. Inferioritas itu telah berlangsung bahkan sebelum kebijakan pelarangan muslim bepergian dikeluarkan oleh pemerintah AS di bawah kepemimpinan Trump. Sejak kampanye perang atas terorisme dan ekspansi AS ke Timur Tengah inferioritas negara-negara Islam di kancah internasional telah nyata.

\section{Perang Melawan Teror dan Ekspansi AS ke Timur Tengah}

Pasca September Hitam, wacana terorisme kental mewarnai retorika politik internasional. AS terus mendorong wacana ini dengan disertai kebijakan politik luar negeri yang agresif terhadap teroris sangat memengaruhi dinamika politik internasional. Tindakan ini berdampak ke beberapa negara Islam karena doktrin yang dianut AS adalah serangan pendahuluan (pre-emptive strike). Doktrin tersebut membuat AS merasa berhak untuk masuk dan menyerang negara yang dianggap sebagai sarang teroris (Hasan, 2012). Korban awalnya adalah Afghanistan dan Irak.

Dari peristiwa pendudukan Afghanistan dan Irak oleh AS, ada beberapa hal yang bisa ditelaah. Yakni; perspektif keamanan yang mewujud dalam perang melawan terorisme seringkali disandingkan dengan isu kebebasan dan demokrasi. Ekspansi Afghanistan bisa menjadi contoh konkret bagaimana pendekatan keamanan global seolah melegitimasi AS untuk melakukan ekspansi. Hal ini serupa dengan isu senjata pemusnah massal yang didengungkan sebelum dan tatkala menyerang Irak.

Pelanggaran teritorial negara yang dilakukan AS dalam 
ekspansinya ke Afghanistan dan Irak menjadi persoalan serius dalam konteks hubungan internasional. Namun wacana keamanan global dan kebebasan yang dalam asumsi AS akan diperoleh Irak dan Afghanistan ketika menerapkan demokrasi seolah membungkam suara penolakan. Adapun klaim keberadaan senjata pemusnah massal di Irak yang akhirnya tidak terbukti semakin menampakkan bahwa ada persoalan yang mengendap- di balik kebijakan perang melawan terorisme dan demokratisasi negara Islam oleh AS.

Berdasarkan beberapa fakta yang ada, David Harvey menyebut ekspansi AS ke berbagai negara Islam di Timur Tengah sebagai bentuk imperialisme baru (Harvey, 2011). Terlebih jika menilik proyek demokratisasi AS di negara-negara Islam Timur Tengah tersebut cenderung tebang pilih. Hal itu tergambar pada hubungan AS dengan sekutu negara Islam utamanya di Timur Tengah yaitu Arab Saudi yang bersistem kerajaan. Hingga kini tidak ada desakan atau usaha pihak AS atas pemerintah negara Saudi untuk mengubah tata pemerintahannya menjadi demokrasi.

AS juga punya peran penting dalam kudeta presiden Mesir,
Mohamed Morsi, pada tahun 2013. Morsi sebagai presiden terpilih dalam pemilu yang sah dikudeta oleh pihak militer yang saat itu didukung oleh pemerintah AS (Roberts, 2013). Diketahui kemudian bahwa pihak AS menolak menyebut pendongkelan Morsi dari kursi presiden oleh militer sebagai kudeta. Hal ini bisa dipahami karena pelabelan kudeta militer dalam demokrasi Mesir akan menutup jalan pemerintah AS sendiri untuk mengintervensi Mesir. Karena dalam konstitusi AS, pemerintah negara tersebut mesti memutus hubungan dengan negara yang presiden terpilihnya mengalami kudeta (Holland, 2013). Sedangkan Mesir adalah negara yang strategis bagi kepentingan AS di kancah internasional. Karena secara geografis Mesir menjadi titik temu Mediterania, Afrika, dan Dunia Arab. Selain itu, Mesir adalah negara terbesar di Timur Tengah dan berperan penting dalam pengaturan distribusi minyak di Terusan Suez. Secara ekonomi, AS telah memberikan kucuran dana hingga 1,5 triliun dolar per tahun untuk Mesir yang 1,3 triliun dolar di antaranya khusus buat militer (Cenghu, 2013). Kehilangan kontrol atas Mesir akan sangat merugikan kepentingan AS di Timur Tengah 
dan dunia internasional secara umum, karena itu AS mesti mengorbankan demokrasi Mesir.

Sampai di sini, menarik untuk menyimak pernyataan presiden Bush di New York Times pada satu tahun peringatan September Hitam.

"Kita akan menggunakan posisi, kekuatan, dan pengaruh kita yang tak ada tandingannya untuk membangun suatu atmosfer ketertiban dan keterbukaan internasional dimana di dalamnya kemajuan dan kebebasan bisa tumbuh berkembang di banyak negara. Suatu dunia bebas yang tumbuh dalam kedamaian adalah kepentingan jangka panjang yang ingin diciptakan Amerika karena mencerminkan nilai-nilai ideal Amerika yang abadi sekaligus telah menyatukan Amerika dengan sekutu-sekutunya. (Harvey, 2011)"

\section{Imperialisme Baru dan Kepen- tingan Ekonomi AS}

Imperium dalam pandangan Hardt dan Negri adalah subjek politik yang secara efektif mengatur pertukaran (ekonomi) dunia, suatu daulah kekuasaan yang mengatur dunia. Imperium ini berbeda dengan pola imperialisme lama bangsa Eropa. Yang mencolok adalah di masa kini tidak ada teritori yang menjadi batas kedaulatan wilayah sehingga lebih cocok disebut sebagai imperium (Negri, 2001).

Namun dengan pendekatan materialisme geografis -historis Harvey mendedahkan bahwa imperium yang ada saat ini tak jauh berbeda dengan imperialisme sebelumnya. Secara tipologi imperium menurut Harvey bisa dikategorikan dalam dua bentuk. Pertama, model pendekatan halus (soft power) dengan toleransi multikultural serupa imperium Ottoman di masa jayanya yang cenderung bersifat multirateral. Kedua, model pendekatan represif (hard power) dengan kekuatan dan penaklukkan serupa Perancis era Napoleon yang cenderung unilateral (Negri, 2001).

Searah dengan konsepsi tersebut, AS yang notabene adalah negara besar pemenang Perang Dingin telah serupa dengan imperium sebab sifatnya yang unipolar. Meskipun definisi Hardt dan Negri sedikit berbeda dengan Harvey terkait imperium, secara garis besar penjelasannya serupa dan berupaya untuk gambaran tatanan dunia yang unipolar dalam kaitannya dengan perkembangan kapitalisme global.

Dari dua tipe imperium yang telah disebutkan di atas, AS telah menerapkan kekuatannya 
guna menopang kepentingan ekonomi dan politiknya di dunia internasional. Dalam ekspansi AS ke Afghanistan dan Irak terlihat jelas pendekatan hard power yang berorientasi pada penguasaan ruang secara de facto. Irak yang tercatat sebagai negara pemilik cadangan minyak nomor tiga di dunia adalah lahan produktif untuk korporasi-korporasi AS. Cadangan minyak Irak sebelum invansi AS tercatat dalam laporan tahunan OPEC (Organisasi

Negara-negara

Pengekspor Minyak Bumi) berjumlah 115 miliar barel, dengan produksi 1,5 juta barel per hari (Otterman, 2005). Jumlah tersebut hanya kalah dari Arab Saudi dengan 264,3 miliar dan Iran 132,5 miliar barel yang merupakan pemuncak daftar negara pemilik cadangan minyak terbesar dunia (OPEC, 2004). Restrukturisasi Afghanistan dan Irak ke demokrasi bertaut erat dengan kebijakan liberalisasi ekonomi-politiknya secara nyata. Harvey sendiri melihat bahwa Afghanistan dan Irak sebatas langkah awal. Target utama AS adalah penguasaan Timur Tengah secara geografis selaku sumber minyak dunia. Harapannya, dengan mengontrol teritori sumber minyak, AS bisa menyetir perekonomian dunia internasional (Miller, 2006).
Pendekatan yang lebih lembut (soft power ) bisa dilihat dalam kasus pemulihan ekonomi Indonesia pasca krisis moneter yang meruntuhkan sistem perbankan Indonesia tahun 1997. Guna memulihakan krisis tersebut IMF (Dana Moneter Internasional) menyodorkan nota kesepakatan yang menderegulasi dan memprivatisasi perusahaan publik (Badan Usaha Milik Negara) yang sebelumnya dipegang oleh negara. Perlu dicatat bahwa AS adalah penyumbang dana terbesar untuk IMF (Yusuf, 2017).

Nota kesepakatan ini secara konkret menceburkan Indonesia ke dalam arus ekonomi neoliberal. Sektor publik yang awalnya dimonopoli oleh negara jadi terbuka untuk investasi. Secara praktik, tidak ada lagi sektor ekonomi yang tertutup pada investasi asing. Produk hukum perdana yang mengindikasikan hal ini adalah diluncurkannya Undang-undang nomor 10 tahun 1998 tentang Perbankan. Di sana tertera bahwa investasi perbankan diperbolehkan hingga 99\%. Beberapa perubahan signifikan akibat nota kesepakatan tersebut seperti sektor industri karet yang sebelumnya membatasi investasi pada angka $45 \%$ melonjak hingga $100 \%$. Hal serupa juga berlaku untuk pembangunan 
jalan tol dan pengelolaan sampah (Khoiriati, 2017).

Tak bisa ditutupi kepentingan AS sangat kental dalam penandatanganan nota kesepakatan yang disodorkan IMF tersebut. Bahkan Bill Clinton, presiden AS saat itu, menghubungi Soeharto selaku presiden Indonesia secara langsung guna menyukseskan proposal IMF. Dorongan serupa juga dilakukan oleh Kanselir Jerman, Helmut Kohl, dan Perdana Menteri Jepang, Hashimoto Ryutaro (Republika, 2014). Motif yang paling kentara dari desakan AS dan Jepang tentu saja untuk melebarkan elan investasinya sekaligus mengamankan aset ekonomi yang mereka tanam melalui investasi.

Wacana Terorisme dan Ketimpangan Relasi Negara-negara Islam di Kancah Internasional

Dari pelarangan masuk tujuh negara Islam ke AS awal tahun 2017, terlihat jelas bagaimana wacana terorisme berpengaruh dalam hubungan internasional negara Islam di kancah internasional. Pelarangan yang tanpa pandang bulu tersebut seolah menempatkan semua warga negara Islam terkait sebagai teroris yang mengancam AS.
Kebijakan imigrasi Peme-rintahan Trump ini bisa dipahami karena searah konsep pemerin-tahannya yang bertajuk mendahulukan kepentingan AS, "American First". Ini adalah kebijakan populis nasionalistik untuk memproteksi kepentingan AS dari segala bentuk ancaman. Namun dalam penerapannya Trump memakai metode unilateralisme, yaitu bertindak secara sepihak demi kepentingannya sendiri (Pujayanti, 2017). Metode ini menegaskan kembali karakter Imperium AS yang diketengahkan Hardt dan Negri perihal unipolarisme tatanan dunia internasional. Adapun efek yang nyata dari tatanan unipolar adalah ketakberdayaan negara kecil, terutama negara-negara Islam, menghadapi kebijkan politik pelarangan masuk ke AS.

Menyikapi kebijakan tersebut Organisasi Kerja Sama Islam (OKI) hanya mampu mengeluarkan kecaman dan menilai kebijakan ini cuma menyuburkan benih anarkisme dan terorisme di tengah upaya internasional melawan terorisme. Sementara Komisi Tinggi PBB untuk Urusan Pengungsi (UNHCR) dan Organisasi Internasional untuk Migrasi (IOM) sekedar menyeru Pemerintah AS tetap membuka pintu terhadap 
pengungsi dan korban perang (Pujayanti, 2017).

Dari ketujuh negara Islam yang dilarang masuk AS pada kebijakan pelarangan muslim bepergian versi pertama yang merespons tegas hanya Iran. Dalam pernyataan resminya Iran berencana memberlakukan kebijakan serupa. Yakni membatasi warga negara AS masuk ke Iran. Pemerintah Iran menilai kebijkan pelarangan yang dilakukan AS tersebut ilegal. Iran berpendapat bahwa pemerintah AS menerapkan "standar ganda" dalam kebijakannya memerangi terorisme mengingat negara lain seperti Arab Saudi, Mesir, Lebanon, Uni Emerat Arab tidak disertakan dalam daftar. Padahal dari negara-negara tersebutlah asal para pelaku teror 9/11 (Chapple, 2017). Menanggapi pelarangan itu Irak, Yaman, dan Sudan hanya menyayangkan tindakan yang telah diambil pemerintah AS. Secara terang pemerintah Irak dan Yaman justru memahami alasan keamanan yang mendasari langkah Presiden Trump itu. Sedangkan empat negara sisanya; Yordania, Libia, dan Somalia tidak merespon (Charlie Brinkhurst-Cuff, 2017).

Bersamaan dengan pelarangan itu, Presiden Trump juga menge-sahkan sebuah perintah penangguhan penerimaan pengungsi dan penerapan pengawasan ketat bagi wisatawan dari negaranegara Islam. Protokol ini secara khusus melarang pengungsi Suriah masuk ke AS hingga waktu yang tidak ditentukan. Aturan eksekutif ini memastikan pemerintah AS menangguhkan sementara seluruh program penempatan pengungsi di AS untuk setidaknya 120 hari ke depan (Suastha, 2017).

Bahkan pada 7 April 2017, pasukan militer AS secara frontal menyerang pangkalan udara Suriah. Serangan udara pasukan AS terhadap Suriah tersebut menembakkan 59 pucuk rudal jenis Tomahawk ke pangkalan udara Shayrat di Suriah Barat (Hutapea, 2017). Trump mengatakan bahwa serangan tersebut demi keamanan nasional AS dan mencegah penggunaan senjata kimia. Dalam pernyataan yang dibacakan di kediamannya West Palm Beach, Florida, pada April 6, 2017 Trump menyeru, "Malam ini, saya memanggil semua bangsa beradab untuk bergabung dengan kami untuk mengakhiri pembantaian dan pertumpahan darah di Suriah dan juga untuk mengakhiri terorisme dari apapun"

(Rampton, 2017). 


\section{Kesimpulan}

Dari pemaparan di atas, perang atas terorisme yang merupakan bentuk kebijakan politik luar negeri AS telah memberikan dampak negatif pada negara-negara Islam di kancah internasional. Kebijakan pelarangan masuk warga negara Islam ke AS yang berkait dengan perang atas terorisme yang berdampak pada 80 juta warga negara Islam sangat merugikan kepentingan negara dan individu Islam di kancah internasional. Meski pada awalnya banyak suara protes atas kebijakan pelarangan, namun dengan legitimasi wacana ancaman terorisme yang melekat pada Islam telah memberikan keleluasaan pemerintah AS menjalankan kebijakan diskriminatif tersebut.

Kebijakan pelarangan muslim bepergian secara internal telah menadapat dukungan melalui penetapan Mahkamah Agung AS bahwa kebijakan tersebut absah dan tidak melanggar konstitusi. Kebijakan tersebut cukup memberikan stabilitas politik bagi pemerintahan baru Trump karena bertahan hingga versinya yang ketiga. Adapun suara penentangan dan gugatan atas kebijakan tersebut tidak lantas membuatnya surut. Pendiaman yang dilakukan oleh pemerintah negara-negara besar di dunia, bahkan Perancis secara terang kemudian mendukung, semakin menegaskan sokongan politik kebijakan diskriminatif tersebut.

Sejak wacana perang terhadap teroris digencarkan pasca peristiwa 9/11, telah banyak negara -negara Islam yang dirugikan oleh wacana tersebut. Secara ekonomi Irak adalah bukti nyata bagaimana sebuah negara Islam porak-poranda ekonominya akibat ekspansi AS. Dalam aspek tatanan sosial selain Irak dan Afghanistan, contoh yang baru adalah Mesir dan Syria yang bergejolak pemerintahannya akibat intervensi AS dengan dalih demokratisasi. Dalam ranah hubungan internasional, profil teroris yang melekat akibat wacana perang atas terorisme AS telah menyulitkan negara-negara Islam menjalin hubungan, menegosiasikan kepentingan, dan meraih dukungan di kancah internasional. Oleh karena itu, negara-negara Islam yang notabene negara berkembang semakin timpang posisinya dibanding negara-negara maju di kancah internasional.

\section{Daftar Pustaka}

Arif, Syaiful. Deradikalisasi Islam:

Paradigma dan Strategi Islam 
Kultural. (Depok: Koekoesan, 2010)

Desai, Meghnad, Rethinking Islamism the Ideology of the New Terror, (New York: Palgrave Macmillan, 2007)

Ditrych, Ondrej Tracing the Discourses of Terrorism, (New York, Palgrave MacMillan, 2014)

Khoiriati, Siti Daulah, Materi Kuliah Umum Ekonomi Politik Indonesia pada 28 Oktober 2017 di UIN Sunan Kalijaga, tidak diterbitkan.

Hardt, Michael and Antonio Negri, Empire, (Harvard University Press, fourth edition, 2001)

Hasan, Noorhaidi. Islam Politik di

Dunia Kontemporer.

(Yogyakarta: SUKA-Press, 2012)

Harvey, David, Imperialisme Baru, (Yogyakarta, Resist Book, 2010).

Hendropriyono, A. M.. Terorisme Fundamentalis Kristen, Yahudi, Islam.(Jakarta: Kompas, 2009). Miller, Christian, Blood Money, (Jakarta, Ufuk Press, 2006).

Pujayanti, Adirini, Kebijakan Imigrasi Pemerintahan Presiden Donald Trump, Majalah Info Singkat Hubungan
Internasional, Vol. IX, No. 03/I/ Puslit/Februari/2017

Wuryandari, Ganewati, Politik Luar Negeri Indonesia di tengah Arus Perubahan Politik Internasional, (Yogyakarta, Pustaka Pelajar, 2011)

ht t p s://ww w.npr.org/s e c t i o n s / t h e t w o way/2017/01/30/512438879/7targeted-countries-react-totrumps -ban -on-immigration diakses pada 8/12/2017 diakses pada 24/11/2018 https://www.theguardian.com/ usnews/2017/jan/29/muslimmajority-countries-anger-attrump-travel-ban diakses pada 24/11/2018

https://www.cnnindonesia.com /i nternasiona $\quad 1 / 201701 \quad 28104$ 545-134 - 189670/t rump-tekenpelarangan-se mentara-imigrandari-7- negara-m uslim/ diakses pada $24 / 11 / 2018$

http://w w w. republika . co. id/ berita/koran/teraju/14/10/27/ ne37891-pertarungan-terakhirsoeharto-vs-imf diakses pada 24/11/2018

https://t ir to. id/k i 1 as - b a li k indonesia-imf-selama-krisisekonomi-asia-cs6F diakses pada $24 / 11 / 2018$ 
http://www.bbc.com/indonesia/ dunia-38808189 diakses pada $24 / 11 / 2018$

h t t p s : / / n e w s.detik.com / internasional/d-3468427/iniyang-kita-tahu-mengenaiserangan-rudal-as-ke-suriah diakses pada 24/11/2018 https://tirto.id/trump-alasanmengapa-saya-menyerangsuriah-dengan-rudal-cmhE diakses pada 24/11/2018

ht tps://edition.cnn.co $\mathrm{m} / 2013 / 07 / 27 / \mathrm{us} /$ september-11-anniversaryfast-facts/index.html diakses pada $5 / 1 / 2019$

h t t p s : / / w w w . b b c.co.u k / newsround/38794001 diakses pada 5/1/2019

https://www.independent.co.uk/ news/world/americas/donaldtrump-muslim-travel-bansupreme-court-appeal-whitehouse-iran-libya-syria-yemensomalia-chad-a8066661.html diakses pada 5/1/2019 https://www.britannica.com/topic/ war-on-terrorism diakses pada $14 / 1 / 2019$

h t t p s : / / w w w. the guardi a $n$. com/world/2001/sep/21/ september11.usa13 diakses pada 14/1/2019 https://www.nytimes.c o m/ $2018 / 07 / 01 / \mathrm{w}$ or $1 \mathrm{~d} /$ americas/travel-bantrump-how-it-works.html diakses 16/1/2019

h t t p s : / / w w w . ny t i me s. com/2018/06/26/us/politics/ supreme-court-trump-travelban.html?action=click\&modu le $=$ RelatedCoverage $\&$ pgtype $=$ Article\&region $=$ Footer diakses pada 15/1/2019

https://www.washingtonpost. c o m / $\mathrm{new}$ s / w orld vi e w s / w $\mathrm{p} / 2018 / 06 / 27$ / fore ig n - critics - of - trumps - travel ban - face - a - new - foe - the s u p r e m e - c o u r t / ? u t m _ term=.0d74994a3859 diakses pada 15/1/2019

https://www.theguardian.com/ world/2013/jul/03/egyptobama-us-mohamed-morsicrisis diakses pada 16/1/2019 https://www. huffingtonpost . com/2013/07/08/white-houseegypt-coup_n_3562857.html diakses pada 16/1/2019 https://www.foreignpolicyjournal. com/2013/07/06/us-backed-c o u p - h i j a c k s - e g y p t s - revolution/ diakses pada $16 / 1 / 2019$ https://www.opec.org/library/ Annual\%20Statistical\%20 
Bulletin/interactive/2004/

FileZ/XL/T33.HTM diakses pada $16 / 1 / 2019$

https://www.reuters.com/article/

us-mideast-crisis-syria-text/ text-trump-statement-on-u-

s-military-strikes-in-syriaidUSKBN1790A1 diakses pada $16 / 1 / 2019$ 
